\title{
Speaking as Prerequisite to Socialisation in the General Curriculum of the Lithuanian Language Education (as Mother Tongue)
}

\author{
Raimonda Jariené $\dot{1}^{1}$ Vilija Saliené ${ }^{2}$ \\ 1 Lithuanian University of Educational Sciences, Faculty of Lithuanian Philology, Department of Lithuanian \\ Language and Literature Didactics, T. Ševčenkos St. 31, LT-03111 Vilnius, Lithuania, raimoda.jariene@gmail.com \\ 2 Lithuanian University of Educational Sciences, Faculty of Lithuanian Philology, Departmentof Lithuanian \\ Language and Literature Didactics, T. Ševčenkos St. 31, LT-03111 Vilnius, Lithuania, vilija.saliene@leu.lt
}

\begin{abstract}
The article focuses on the analysis of expression of speaking, as a prerequisite to socialization, in the curriculum of the Lithuanian language as mother tongue. The theoretical part compares two learning theories making attempts to highlight the importance of speaking to cognitive and social achievements of learners. The theoretical analysis is based on the comparison of the approaches of two learning theories, that is, constructivism and social constructivism. The research part of the article analyses the dual purpose of speaking, i.e., as learning object and as learning tool, and its expression in the general curriculum of the Lithuanian language (as mother tongue) for basic school.
\end{abstract}

Keywords: constructivism, socio-cultural learning theory, socialization, speaking, curriculum of the Lithuanian language (as mother tongue).

\section{Introduction}

The educational discourse has been undergoing systematic reconsideration of educational goals and ways of their implementation since the second half of the 20th century and the beginning of the 21st century. Over the last decades the attitude has been expressed that contemporary education has to be based on the open, authentic, explorative and critical dialogue of participants of the process of education. Speaking and communication are inevitable conditions of the activity of a modern person living in a complicated 
dynamic world. Development of learners' critical thinking, as well as abilities to discuss, understand and assess different approaches is one of the most important goals of documents regulating the national educational curriculum. Learning is often perceived as a social activity implemented through discursive practice.

The whole interaction in the classroom is based on the use of language. The use of language helps to acquire new knowledge and awareness, identify awareness problems, acquire and develop abilities, establish and maintain relationships, as well as create, develop and restrict possibilities in the process of learning. The nature of language use reflects tacit expectations of the participants of educational process, the conceptions of knowledge, learning and own roles, as well as the rules of common existence, or otherwise, learning culture in its broadest sense. Scientists have come to a common agreement that the cognition of the links between speaking, interaction and learning helps to understand the essence of learning (Barnes, 2012; Cazden, 2001; Alexander, 2011; Mercer, Littleton, $2007,2013)$. The quality of interaction is frequently related to learners' capacities to express own understanding and ideas, to perceive understanding of others, to explore and question own and others' understanding, i.e. construct own knowledge through constructive and critical dialogue with other people. Lithuanian specialists of mother tongue didactics have not analysed how and to what extent speaking and communication serve as prerequisites for a learner to become a responsible member of the society; therefore, the research problem of the current article is to analyse which learning conception (constructivist or socio-cultural) the general curriculum of the Lithuanian language as mother tongue is based on. The object of the research is the expression of constructivist and socio-cultural learning theories in the general curriculum of the Lithuanian language as mother tongue. The aim of the research is to reveal which learning theory (constructivist or socio-cultural) the general curriculum of the Lithuanian language as mother tongue is based on, and to discuss the expression of speaking as a prerequisite of socialization. The research objectives are as follows: 1) to define constructivist and socio-cultural approaches to learning; 2) to analyse whether the aims, objective learning outcomes and education guidelines defined in the general curriculum of the Lithuanian language as mother tongue are based on the provisions of socio-cultural learning theory. Research methods include comparative analysis of scientific literature and qualitative analysis of the general curriculum of the Lithuanian language as mother tongue.

\section{Theoretical prerequisites of the analysis}

Contemporary education is largely affected by two learning theories: constructivism and social constructivism. They can be considered as a response to the behaviourist learning conception, which claims that knowledge, i.e. a certain defined 'set', is transferred to the learner who is considered to be its passive and externally motivated recipient. 
According to behaviourists (B.F. Skinner being the most prominent representative), the learner thinking process is non-cognizable, and thus, it is possible to explore only the mutual dependence of the organization of teaching and learner behaviour. This approach to learning has largely been criticized for the debasement of the role of the learner.

Constructivist theory of learning is based on a different epistemological approach and emphasizes an active role of the learner. Knowledge is not what is taken or discovered by a human being from the surrounding world: knowledge is constructed by people. Hence, behaviourist conviction that human thinking is non-cognizable is changed by an approach stating that it is possible to explore and cognize human intellect and processes of information processing. Learning is perceived as an active activity of information processing and knowledge construction by an individual. A significant impact on the formation of the approach to learning was made by the ideas of cognitive psychology developed by the Swiss psychologist J. Piaget. Piaget (2001) considers intellect as a way of body adaptation to the environment. While interacting with the environment, a human being creates a lot of schemes of behaviour. Every new situation causes difficulties of recognition and choice of behaviour for a human being, i.e. $s$ / he loses the balance. Cognition occurs in pursuance of restoring the destroyed balance between oneself and the environment. As soon as new information does not contradict the old one, it is integrated into the old structures of cognition (assimilation). When the new information does not comply with the old one, it is accepted only when the old schemes are transformed (accommodation). A human being is constantly put in new situations, and thus, actively develops his / her knowledge. Human behaviour is stimulated not by external stimuli, but rather by active nature of the intellect.

This theory basically changes understanding of learning at school. Learning is perceived as active work of learners: it involves constant intellectual effort in developing own understanding and abilities, in developing and changing own beliefs, as well as continuously relating the old knowledge, understanding and experience with the newly acquired experiences and the changing socio-cultural context. Such a conception of learning changes not only the understanding of learner roles in the process of learning, but also encourages reconsidering the role of the teacher and main didactic principles. In the light of the constructivist conception of knowledge, methods of retelling have become unreliable. The teacher's ability to disclose and employ learners' awareness is of particular significance. This is illustrated by the didactic maxim of D. Ausubel (cited in Graves et al., 1998): "If I had to reduce all of educational psychology to just one principle, I would say this: The most important single factor influencing learning is what the learner already knows. Ascertain this and teach him accordingly". Hence, the learner is an active creator of meaning that rests upon own unique experience. Interaction is essential for the development of his / her understanding. Understanding and attitudes expressed by other people provide opportunities for learners to experience productive tension: while encountering with a different understanding and acknowledging different prospects, 
assumptions and convictions, learners revise their own understanding, question own thoughts, assumptions and convictions, and start asking themselves whose - own or others' - convictions seem more likely to be true.

Despite that cognitive approach to learning emphasizes significance of interaction, the place of learning, metaphorically speaking, is the head of the learner. Such an approach to learning has been regarded as insufficient as it draws too little attention to the socio-cultural context and demonstrates a narrow understanding of learning aims. Packer and Goicoechea (2000) analyse epistemological and ontological prerequisites of the constructivist approach to learning and maintain that Piaget, following Kantian tradition, perceived a human being as a thinking "epistemic person", who does not undergo any fundamental changes while constructing knowledge. This does not suffice society that emphasizes responsibility, participation, creativity and innovation (Kalantzis, Cope, 2012).

The impact of the ideas of social constructivism has been developing since the beginning of the 9th decade of the 20th century. Socio-constructivist approach to cognition is based on the assumption that any cognition, knowledge or knowing, as well as the reality itself are a construct of common human social activity (Pritchard, Woollard, 2010). Teaching and learning are social processes that occur not in human heads, but among people. Learning occurs in a specific context that is characterized by certain physical, emotional, social, cultural and historical features determined by the context itself. Teaching and learning are largely discursive practices, since language is "an especially efficient semiotic means, $<\ldots>$ that enables its users to communicate aiming at the coordination of own activity and simultaneously rethink the acquired experience, as well as share its interpretations" (Wells, 1999, p. 35).

One of the most important pillars of social constructivism is cultural historical theory of psychological processes of the Russian psychologist L. Vygotsky.

Vygotsky (2005a) considered the theories of inheritance and external determination that prevailed in classical psychology as insufficient to explain the complex development of human mental powers. He distinguished two levels of mental functioning: the lower and the higher levels. According to Vygotsky, the functions of the lower level, such as reactive attention, sensory and motor thinking are innate and hereditary. Their development is based on natural biological self-development. However, the functions of the higher level are of social nature and were considered by the scholar as a socio-cultural construct that is not innate but rather acquired during social interaction and developed in the historical cultural process.

Vygotsky (2005a) explained the development of the higher mental functions and stated that two lines of behaviour development of a modern cultured person should be distinguished: the process of his / her biological development and the process of his/ her historical cultural development. Culture "develops particular forms of behaviour, alters the activity of mental functions and builds new storeys in the developing system of human behaviour. <..> In the process of historical development, a social individual 
changes ways of his / her behaviour, transforms innate givens and functions, develops and creates new - specifically cultural - forms of own behaviour" (2005a, p. 233). These two lines - biological natural and historical cultural - also mark the development of higher mental functions of a child. One line of the development is related to self-contained human growth and maturation; the other is linked to the development of cultural psychological functions, new ways of thinking as well as mastering of cultured behaviour.

A child does not 'absorb' these forms from culture directly; they are interiorized through common activity with others using sign systems that a human being has created to maintain and coordinate social relations. These semiotic systems perform the function of cultural mediation between children and the environment. Vygotsky refers to the systems of signs as supplementary psychological means due to their mediatory function. Such psychological means are language, different calculation systems, writing, art works, different systems of arbitrary signs, etc. A child employs these means primarily in social interaction aiming at producing an impact on others or experiencing one from others; eventually, they start using these systems to regulate own behaviour. According to Vygotsky, the common genetic law of cultural development can be formulated as follows: in the process of child cultural development any function "occurs twice: firstly, on the social level, and later, on the psychological level; firstly, as inter-mental category of human, and later, as intra-mental category of a child. This also pertains to focused attention, logical memory, development of concepts and development of will <..." (2005a, p. 355). Transformation of the ways of social behaviour and external operations into internal is called interiorization, that is often referred to as "in-growth process".

The idea of the formation of socio-cultural higher functions radically changes approach to development. Vygotsky disputes with Piaget and states that the main trend of development id not the movement towards socialization, but vice versa - movement from the social to the individual. Therefore, Vygotsky maintains that seeking to understand child development, we should ask "how does a group create higher mental functions of a child?" rather than ask about a child's behaviour in a certain group (2005a, p. 357). The assumption that individual functions are givens that are disclosed in social interaction and become more complicated, or on the contrary, their natural development is suspended or suppressed, is changed by an opposite perception: the functions primarily occur as relations in a group and later develop into mental functions.

As it was stated above, a system of signs, or the mediating role of psychological means relate social and individual levels and enable the process of internalization. Vygotsky (2005b) considers language as the most significant psychological means and maintains that language and thinking are inseparable.

The theory of the development of higher socio-cultural mental functions has several important implications in education practice. Education and learning are considered as a largely social process. Therefore, social environment, where human self-development 
occurs, is considered not as a factor of self-development, but as an important source of self-development. The development of cognitive capacity and the formation of thinking habits of a child depend on the quality of social interaction. Interaction is a key factor that determines whether a child will successfully develop cognitive capacities, and whether some of these capacities will not be neglected provided they are not offered in the interaction. Despite the fact that the teacher cannot directly affect the learner, the learner can learn and develop on his / her own. The teacher, however, can influence the learner indirectly by changing the social environment. According to Vygotsky (1996), the teacher is primarily organizer of the teaching environment. When the teacher substitutes the book and becomes the main source of knowledge, $s$ / he does not perform the role of an educator any longer. The teacher performs his / her role best when $\mathrm{s} /$ he is able to retreat and enable a favourable impact of environmental power.

Environment that is favourable for learning is the one where teaching outstrips child development. This is best illustrated by Vygotsky's (2005b) conception of the 'zone of proximal development'. The zone of proximal development is perceived as a difference between the current level of child development, which defines the problems that can be solved by a child independently, and the potential level of development, which is defined by problem-solving coordinated by an adult or cooperation with more gifted peers. If the support is appropriate and meaningful, the child's understanding can develop and surpass what $s$ / he could have achieved relying basically on own capacities. Hence, understanding of the impact of mediation with more knowledgeable people acquires greater significance in the context of socio-cultural approach to education.

The ideas of socio-cultural approach to learning are intensively developed in modern educational discourse. Development of a child's learning and cognitive capacities, as well as reasons of successful and unsuccessful learning are not confined merely to learners' individual abilities, didactic abilities of individual teachers or quality of applied methods and learning means, but is related to the quality of social and communicative processes in the classroom (Wells, Claxton, 2002, Mercer, Littleton, 2007, Barnes, 2012, Alexander, 2011).

Following Vygotsky's idea of 'the zone of proximal development', Mercer and Littleton $(2007,2013)$ develop the idea of 'intermental development zone'. The use of oral speech enables human beings to think collectively. This process can be referred to as interthinking. The scholars consider the use of speech for collective thinking as the main achievement of humanity and a distinctive feature of human nature that is meant to satisfy practical and social needs of individuals and communities. The development of understanding how to employ language for the integration of own intellectual resources can have some beneficial practical outcomes, especially for education. Every child has to learn how to employ language for common thinking. The first thing to be done is to acknowledge that language performs a special function of collective thinking; otherwise, its social and psychological significance can be underestimated (Mercer, 2000). 
So that a teacher could teach and children could learn, they have to use language and get involved into common activity, and thus, create a communicative space, i.e. 'intermental development zone', which is based on the context of knowing and common aims. The teacher and learners make continuous agreements regarding the ways of common activity in the intermental zone, which undergoes constant changes due to the ongoing dialogue. If the quality of the zone is successfully maintained, the teacher can help learners to overcome the limits of own capacities and change their experience into new abilities and understanding. Provided the common zone of teacher-learner common thinking is not maintained by dialogue, intermental development zone 'fails' and learning based on support does not develop.

Similarly to Vygotsky's zone of proximal development, the conception of intermental development zone focuses on learners' progress and guidance; however, the latter conception stresses both the teacher's and the learner's roles. Intermental development zone is perceived as a continuous common activity that occurs in a particular context and whose quality depends on the knowledge, abilities and motivation of both teachers and students. Mercer (2000) maintains that if we acknowledge that good teaching affects learning and the teacher's contribution to learning outcomes is important, we have to acknowledge that achievements are an outcome of common activity and common thinking. Let us imagine two hypothetical learners. Their progress can be different as it largely depends on the support they have received and their own response to the provided supervision. Hence, the implication of intermental development zone on cognitive development and the studies of teaching and learning process can be as follows: when we monitor the progress of a learner or a group of learners that is supported by the teacher and provided through particular activity, we should also monitor the use of language and communication means that can create intermental development zone and are employed by both teachers and learners (Mercer, 2000).

Socio-cultural approach to learning emphasizes that learning is related not only to the development of cognitive capacities, but also to qualitative changes of personality. According to Packer and Goicoechea (2000), socio-cultural approach to learning is based on a different ontological prerequisite than cognitive approach. Learning is not confined to mere cognitive activity. It is related to human development into someone who s/he is not at the moment. The scholars generalize the essence of this process in the following way: personality is created (developed and transformed) within the social context through practical activity of a certain community and the existent human relations, in which a person seeks not only for cognition, but also for recognition. Activity and relations in the social context can destroy personal integrity. To become a human being means to undergo fragmentation; to become a member of community means to be split. Discourse and social practice help to develop human relationship with oneself, others, activities and the world, as well as act as mediators of these relations. The community defines ways of recognition and relations through which this recognition can be achieved. Having lost 
his/her integrity, a human being lacks identity and starts striving for it. These are his / her active attempts to become someone who s / he has not been so far. Hence, his / her nature is transformed into culture in a community.

However, culture is not only reproduced in the process of learning, but it is also renewed. A learner not only learns of thinking and speaking ways that are commonly accepted in the society. S / he also searches for new ways of constructive problem-solving in the process of common activity and learning (Wells, Claxton, 2002, Littleton, Mercer, 2013). Creative endeavour of local communities that may seem insignificant at the first sight can underlie major socio-cultural changes in the society. Hence, learning is both a person's introduction into culture, socialization and enculturation, as well as an activity of culture renewal.

\section{The analysis of research results ${ }^{1}$}

Despite wide acknowledgement of the links between the quality of speaking and development of learners' cognitive powers, speaking has not achieved the level as it should so that it efficiently and sustainably involves learners into cognitive activity, helps them develop understanding, as well as mobilizes efforts of interaction participants while creating dialogue-based learning environment. Such a conclusion is regularly drawn by scholar of the United Kingdom and the United States who have analysed different aspects of classroom discourse (Nystrand et al., 1997; Cazden, 2001; Alexander, 2004).

Some scholars (Barnes, 2012; Mercer, Dawes, 2012) believe that one of the reasons of the poor quality of speaking is that some learners do not understand how and for what purposes language should be used while learning. Children can misunderstand and underestimate importance of communication for learning. It happens because speaking is often taken for granted; teachers seldom discuss successful usage of language in common activity despite prior explanation of general aims of speaking, and explicate how successful use of language relates to learning opportunities. Attention to efficient language use in common activity is one of the most significant prerequisites of successful learning and socialization; therefore, it should be considered in documents regulating the curriculum and the quality of speaking should be explicitly defined.

Language plays a dual role at school: on the one hand, it is the object of learning; on the other hand, it is a tool of learning. Development of learners' communicative skills is one of the general outcomes that has to be implemented in classes of all study subjects. Therefore, description of communicative competence is provided in the general curriculum, where communicative competence is defined as an ability to constructively

1 General Curriculum of the Lithuanian Language as Mother Tongue is discussed from the point of view of speaking as a prerequisite of communication. 
participate in a dialogue and use the language in a responsible way; to understand and convey different verbal and non-verbal messages, to communicate with regard to the aim, addressee and situation of communication; to find, critically assess and summarize information as well as present it appropriately to others (Programa, 2009).

The study subject of Lithuanian as mother tongue is unique because it refers to speaking (oral language) as to the object and a learning tool. The aim of the current analysis is to reveal / explore how these two aspects are expressed and how the opportunities for socialization through language are reflected in the general curriculum of the Lithuanian language as mother tongue, i.e. how the aims, objectives and content help a learner to develop communicative competence and become a member of a productive dialogue. Pursuing to achieve the aim, the following structural parts of the curriculum of the Lithuanian language as mother tongue have been explored: introduction into the field of linguistic education, the aim and objectives of the school subject, learning outcomes and education guidelines, and assessment.

The introductions into the field of linguistic education and the curriculum of the Lithuanian language as mother tongue maintain that the primary aim of linguistic education is provide preconditions for learners to develop communicative and cultural competences. It is stated that the purpose of linguistic education in basic school is to develop a conscious, responsible and self-confident language user and its critical recipient. This aim can be achieved by developing communicative culture in language classes, i.e. by learning to listen to another person and respect his / her opinion, defend own viewpoint, avoid infringing others' and own dignity, developing responsibility for the accuracy and authenticity of one's sayings (Programa, 2009). Educational environment should be perceived as not only as space of learning, but also as a constant cooperation, the success of which depends on the commitment of every member of the community to assume responsibility, share experience, information and ideas as well as hear each other. Hence, the goal of the introduction into linguistic education and the introduction of the Lithuanian language as mother tongue to provide conditions for acquiring experience of cultured discussion is clearly defined. The conception of the culture of discussion emphasizes respect for a different opinion and the ability to appropriately defend own viewpoint. However, it is not enough to emphasize the defence of own viewpoint, but also stress that this viewpoint should be justified. Attention should also be focused on the fact that in a discussion people not only exchange ideas and approaches, but also question and change their beliefs depending on the validity of arguments, and seek to explore and acquire better understanding of the issue under discussion. A young person is more often challenged not by the expression of own viewpoint, but rather readiness and ability to question it. Speaking and listening as the object of learning are considered one of the structural parts of the curriculum alongside with reading, literature (culture) studies and writing. The analysis of the description of speaking and listening skills reveals that monologue and interactive speaking as well as active listening receive considerable 
attention. The last position of the curriculum, description of learning outcomes, defines abilities and skills of learning to learn. A closer analysis of this part of the descriptor of learning outcomes reveals that the position of learning to learn focuses largely on monologue speech. The phrases that are highlighted in Table 1 show that pre-trained speaking receives more attention, whereas reflection of interactional experience is not highlighted.

Table 1. An extract from the description of the development of school learners' abilities

\begin{tabular}{|c|c|c|}
\hline Forms 5-6 & Forms 7-8 & Forms 9-10 \\
\hline \multicolumn{3}{|c|}{ Speaking and listening } \\
\hline $\begin{array}{l}1.10 \text {. To apply strategies offered } \\
\text { by a teacher while preparing } \\
\text { for or in the process of spe- } \\
\text { aking. To reflect the activity of } \\
\text { own speaking and listening un- } \\
\text { der the teacher's supervision: to } \\
\text { explain the points of success and } \\
\text { failure and their reasons, as well } \\
\text { as provide arguments on possible } \\
\text { changes in the future. }\end{array}$ & $\begin{array}{l}\text { 1.10. To choose appropriate } \\
\text { strategies for preparing for } \\
\text { speaking or for the process of } \\
\text { speaking. On the basis of obser- } \\
\text { vation of own speaking activity } \\
\text { and others' feedback, to clear out } \\
\text { which of the employed strategies } \\
\text { are suitable for problem-solving, } \\
\text { to foresee areas of the develop- } \\
\text { ment of speaking skills and to set } \\
\text { learning goals. }\end{array}$ & $\begin{array}{l}\text { 1.10. To purposefully employ } \\
\text { the most appropriate strategies } \\
\text { for preparing for speaking } \\
\text { or for the process of speaking. } \\
\text { On the basis of observation } \\
\text { of own speaking activity and } \\
\text { others' feedback, to clear out } \\
\text { which strategies for preparing for } \\
\text { speaking (language content and } \\
\text { planning of speaking), as well as } \\
\text { the strategies for the process of } \\
\text { speaking are personally suitable, } \\
\text { to foresee the areas of the deve- } \\
\text { lopment of speaking skills and to } \\
\text { set learning goals. }\end{array}$ \\
\hline
\end{tabular}

The dominance of presentational language and possibly unfavourable outcomes of learning are analysed by the researchers of class discourse. Barnes (2012) tries to explore what type of learners' speaking is most beneficial for the development of their understanding, and thus, defines two types of speaking: exploratory talk and presentational talk. When learners try to understand ideas, they speak hesitantly; the thoughts are incomplete and can easily change their direction. This happens because participants of the interaction try and understand ideas, to hear how they sound, as well as make clarifications and adjustments. This makes their speaking considerable different from the fluent presentational talk. The difference between presentational and exploratory talk lies in the fact that in case of presentational talk attention is focused on how the language, content and ways of speaking should be adjusted to audience needs, whereas the focus of exploratory talk is the development of own understanding during a conversation. According to Barnes (2012), teachers frequently demand presentational talk too early when their learners have not passed the stage of exploratory talk yet. Therefore, he recommends creating a favourable environment from the psychological point of view, so that learners feel safe enough to voice their thoughts and exchange incomplete and 
vague ideas without fear of criticism or ridicule. Besides, learners should be aware of the aims and rules of such speaking, as well as be involved into the reflection of speaking.

The analysis of the descriptions of achievements in speaking and listening (Programa, 2009) showed that efficient speaking is not taken for granted and that the general curriculum explicitly describes knowledge, abilities and attitudes, which have to be acquired by school learners in order to become efficient communicators. However, the focus on preventive skills of individual learner's speaking allows to conclude that the construct of the description is based on the constructivist rather than on the socio-cultural learning.

The expression of the language as a learning means is better reflected in the descriptions of educational guidelines (Programa, 2009), which are presented as concise methodological recommendations for teachers. Having reviewed the educational guidelines for reading and literature (culture) learning, it can be concluded that a considerable attention is allocated to reading strategies. The whole model of organizing reading activities is based on application of strategies. The recommendations to plan reading activities in such a way, which would enable school learners to understand the purpose of the reading process (pre-reading, reading and post-reading activities) through practical activities and would get used to their application while reading self-dependently. Guidelines for self-evaluation emphasize individual application of strategies. Thus, development of reading skills is firstly understood as teaching to apply strategies. Socio-cultural attitude towards development of reading skills firstly highlight the necessity and quality of the discussion about the read texts. Educational guidelines for teachers recommend discussions, presentation of open type questions that encourage school learners to draw conclusions and justify them on the material from the literary work and to discuss with each other (Programa, 2009). However, there are no clearly expressed instructions how to encourage teachers to organize reflection of discussion. This reveals that the guidelines of the educational process are modelled on the basis of constructivist rather than on socio-cultural conception of learning.

\section{Conclusions}

1. The constructivist learning theory approaches learning as an individual cognitive activity. Socio-cultural approach considers learning as a socio-cultural activity, which directly related to school learner's socialization.

2. The introductory part of the General Curriculum of the Lithuanian Language explicitly outlines the goal to establish conditions for school learners to develop skills of efficient speaking.

3. The descriptions of achievements and educational guidelines are more based on the constructivist learning theory. 
4. Pursing expansion of opportunities for successful socialization of learners, more emphasis should be laid on the high quality of explorative discussion as a learning object and learning tool; its features are more comprehensively expressed in the descriptions of achievements and clearer explanations are presented for teachers in educational guidelines.

\section{Resources}

Alexander, R. (2011). Towards Dialogic Teaching: Rethinking Classroom Talk. Cambridge: Dialogos. Barnes, D. (2012). Exploratory Talk for Learning. In Exploring Talk in School. N. Mercer, S. Hodgkinson (Eds.). Los Angeles, London, New Delhi, Singapore, Washington DC: SAGE Publications Ltd, 1-15.

Cazden, C. B. (2001). Classroom Discourse. The Language of Teaching and Learning. Portsmouth, NH: Heinemann.

Graves, M. F., Juel, C., Graves, B. B. (1998). Teaching Reading in the 21st Century. Boston, London, Toronto, Sydney, Tokyo, Singapore: Allyn and Bacon.

Kalantzis, M., Cope, B. (2012). New Learning: elements of a science of education. Cambridge, New

York, Melbourne, Madrid, Cape Town, Singapore, Sao Paulo, Delhi, Mexico City: Cambridge University Press.

Littleton, K., Mercer, N. (2013). Interthinking. Putting Talk To Work. London, New York: Routledge. Lukšienè, M. (2000). Jungtys. Vilnius: Alma littera.

Mercer, N. (2000). Words and Minds. How we Use Language to Think Together. London, New York: Routledge.

Mercer, N., Dawes, L. (2012). The Value of Exploratory Talk. In Exploring Talk in School. N. Mercer, S. Hodgkinson (Eds.). Los Angeles, London, New Delhi, Singapore, Washington DC: SAGE Publications Ltd, 55-71.

Mercer, N., Littleton, K. (2007). Dialogue and the Development of Children's Thinking. A sociocultural approach. London, New York: Routledge.

Nystrand, M., Gamoran, A., Kachur, R., Prendergast, C. (1997). Opening Dialogue. Understanding the Dynamics of Language and Learning in the English Classroom. New York, London: Teachers College Press.

Packer, M. J., Goicoechea, J. (2000). Sociocultural and Constructivist Theories of learning: Ontology, Not Just Epistemology. Educational Psychologist, 35 (4), 227-241. Available online at:http://lchc.ucsd.edu/mca/Mail/xmcamail.2009_11.dir/pdfZJWU36cRRA.pdf.

Piaget, J. (2001). The Psychology of Intelligence. London, New York: Routledge Classics.

Piaget, J. (2002). Vaiko kalba ir mastymas. Vilnius: Aidai.

Pradinio ir pagrindinio ugdymo bendrosios programos. (2009). Vilnius: Švietimo aprūpinimo centras. 
Pritchard, A., Woollard, J. (2010). Psychology for the Classroom: Constructivism and Social Learning. London, New York: Routledge.

Wells, G. (1999) Dialogic Inquiry: Towards a Sociocultural Practice and Theory of Education. Cambridge: Cambridge University Press.

Wells, G., Caxton, G. (2002). Introduction: Sociocultural Perspectives on the Future of Education. In Learning for Life in the 21st Century. G. Wells, G. Calxton (Eds.). Oxford, Malden: Blackwell Publishers Ltd, 1-17.

Выготский, Л. С. (1996). Педагогическая психология. Москва: Педагогика-Пресс.

Выготский, Л. С. (2005a). История развития высших психологических функций. In Выготский, Л. С. Психология развития человека. Москва: Смысл; Эксмо (pp. 208-547). Available online: http://yanko.lib.ru/books/psycho/vugotskiy-psc_razv_chel-7-myshlenie_i_ rech.pdf.

Выготский, Л. С. (2005b). Мышление и речь. In Выготский, Л. С. Психология развития человека. Москва: Смысл; Эксмо (pp. 664-1020). Available online at: http://yanko.lib.ru/ books/psycho/vugotskiy-psc_razv_chel-7-myshlenie_i_rech.pdf.

\title{
Kalbejjimo, kaip socializacijos prielaidos, raiška Lietuvių gimtosios kalbos ugdymo programoje
}

\author{
Raimonda Jariené ${ }^{1}$, Vilija Saliené ${ }^{2}$
}

1 Lietuvos edukologijos universitetas, Lituanistikos fakultetas, Lietuvių kalbos ir literatūros didaktikos katedra, T. Ševčenkos g. 31, 03111 Vilnius, raimonda.jariene@gmail.com

2 Lietuvos edukologijos universitetas, Lituanistikos fakultetas, Lietuvių kalbos ir literatūros didaktikos katedra, T. Ševčenkos g. 31, 03111 Vilnius, vilija.saliene@leu.lt

\section{Santrauka}

Straipsnyje analizuojama kalbejimo, kaip socializacijos prielaidos, raiška Lietuviu gimtosios kalbos ugdymo programoje. Teorineje dalyje lyginamos dvi mokymosi teorijos siekiant išryškinti kalbëjimo svarbą kognityviniams ir socialiniams mokinių pasiekimams. Teorinè analizè remiasi dviejų mokymosi teorijų - konstruktyvizmo ir socialinio konstruktyvizmo - nuostatų lyginimu. Tiriamojoje straipsnio dalyje analizuojama dvejopa kalbejjimo - kaip mokymosi objekto ir kaip mokymosi priemonès - paskirtis ir raiška Lietuviu gimtosios kalbos ugdymo programoje pagrindinei mokyklai.

Lietuvoje gimtosios kalbos ugdymo didaktų nèra nagrinèta, kaip ir kiek kalbejjimas ir kalbejjimasis sudaro galimybę mokiniui tapti atsakingu visuomenès piliečiu, todèl šio straipsnio mokslinė problema - paanalizuoti, kuria mokymosi samprata (konstrukty- 
vistine ar socialine-kultūrine) grindžiama Lietuvių gimtosios kalbos bendroji programa pagrindinei mokyklai. Tyrimo objektas - konstruktyvistinès ir socialinès-kultūrinės mokymosi teorijų raiška pagrindinio ugdymo Lietuvių gimtosios kalbos bendrojoje programoje. Tyrimo tikslas - atskleisti, kuria mokymosi teorija (konstruktyvistine ar socialine-kultūrine) remiamasi Lietuviu gimtosios kalbos bendrojoje programoje, ir aptarti kalbejjimo, kaip socializacijos prielaidos, raišką. Tyrimo uždaviniai: 1) aptarti konstruktyvistinị ir socialinị kultūrinị požiūrị ị mokymąsi; 2) išanalizuoti, ar Lietuviu gimtosios kalbos bendrojoje programoje formuluojami tikslai, uždaviniai, mokinių pasiekimai, ugdymo gairès grindžiamos socialinès-kultūrinès mokymosi teorijos nuostatomis. Tyrimo metodai: mokslinès literatūros lyginamoji analizè, bendrosios lietuvių kalbos programos kokybinè analizè.

Tyrimo metu buvo konstatuota, kad konstruktyvistinès mokymosi teorijos požiūriu mokymasis yra individuali kognityvinè veikla, o socialiniu-kultūriniu - socialinè-kultūrinè veikla, kuri tiesiogiai susijusi su mokinio socializacija. Lietuvių gimtosios kalbos bendrosios programos ịvadinejje dalyje aiškiai išreikštas siekis sudaryti sąlygas mokiniams ugdytis veiksmingo kalbejjimo gebejjimus. Pasiekimų aprašai ir ugdymo gairès labiau pagrịstos konstruktyvistine mokymosi teorija. Siekiant plèsti sėkmingos mokinių socializacijos galimybes labiau turètų būti akcentuojamas kokybiškas tyrinèjamasis diskutavimas, kaip mokymosi objektas ir mokymosi priemonė, išsamiau išreikšti jo požymiai pasiekimų aprašuose, pateiktos aiškesnès nuorodos mokytojams ugdymo gairèse.

Esminiai žodžiai: konstruktyvizmas, socialinè-kultūrinè mokymosi teorija, socializacija, kalbejjimas, Lietuviu gimtosios kalbos ugdymo programa. 